\title{
The Hepatitis B Antigen and Antibody of Healthy Donors in a Farm Area.
}

\author{
Terukatsu Arima, M D, and D Sci, *Takehiko Yamamoto, M D, Kenji Jinno, M D, \\ Kenichi TakaI, M D, **Kowichi Nagata, M D, \\ **Takashi TANigawA, M D and **Masanobu IMAI, M D
}

\begin{abstract}
The First Department of Internal Medicine, Okayama University Medical School, Okayama, *Department of Medicine, Kawasaki Medical School, Okayama and **Mitoyo General Hospital, Toyohama, Kagawa.
\end{abstract}

\begin{abstract}
Ausria II-125 and Ausab were used for testing 1,000 sera from apparently healthy blood donors living in a geographically relatively isolated farm area in the northern part of Shikoku-island. Hepatitis B surface antigen was detected in $2.1 \%$ of the donors. The prevalence of antibody to the antigen was $19 \%$. A significant excess of the antigen carriers was detected among males and among donors aged 20-29 years. The frequency of detectable antibody against the antigen increased with advancing age. There was no significant differences in the prevalence of the antibody between males and females. Only 9 male donors were found to have elevated serum glutamyl-oxalacetic-transaminase level. Of these donors with elevated transaminase level, one was with positive antigen and five were with positive antibody.
\end{abstract}

Key Words : Ausria II-125, Ausab, Glutamic-oxalacetic-transaminase, Glutamic-pyruvic-transminase, Serum bilirubin, Alkaline phosphatase, Radioimmunoassay, Liver disease, Age and sex differences, and Epidemiology.

Many articles have described the close relation between hepatitis antigen $(\mathrm{HBAg})$ and hepatitis (1-3). The incidence of HBAg and anti-HBAg (HBAb) in normal population have been reported in several regional studies (4-9). These prevalence were described ranging from $1 \%$ to $3.5 \%$ and $11 \%$ to $25 \%$, respectively. The technique used for these studies were micro-Ouchterlony (MO), single radial immunodiffusion (SRI), immune adherence hemagglutination (IAHA), immunoelectro-osmophoresis (IEOP), passive hemagglutination (PHA), reversed passive hemagglutination (RPHA) or hemaggluti-

Received for publication on May 19, 1977. Address requests for reprints to T. Arima, The First Department of Internal Medicine, Okayama Universtity Medical School, Okayama 700, Japan. nation inhibition (HAI).

Recently a radioimmunoassay (RIA) technique followed by chromatoelectrophoresis was reported that increased the sensitivity of detection of $\mathrm{HBAg}$ by at least 100 -fold and of HBAb by at least 20-fold in comparison with complement fixation technique (CF) (10). Further modification of the radioimmunoassay procedure were achieved by using double antibody precipitations (RIA-DAP) $(11,12)$ and solid phase techniques (RIA-SP) $(12,13)$. A commercial product based on the latter tećhnique became available, but limitations of the assay for HBAg were discussed in several reports because of the presence of false possitive (14-17). Modification of the method by changing incubation time, temperature, or adding normal guinea pig serum to the reaction mixture at second incubation, re- 
duced the non-specific reaction (18). Recently, an improvement of the technique was achieved by using heterologous pighuman antibody sandwich technique (19).

This report summarizes data on the ageand sex-specific prevalence of $\mathrm{HBAg}$ and $\mathrm{HBAb}$ in apparently healthy donors who live in a geographically restricted farm area by using commercial products, Ausria II-125 and Ausab which techniques are based on the heterologous sandwich principle.

\section{MATERIALS AND METHODS}

Donors were enrolled during the period between June 1975, and March 1976, who underwent donation at Mitoyo General Hospital. All donors live in the western part of Mitoyo, Kagawa Prefecture in which part the population is about 50,000 . Mitoyo is a farming county in the northern part of the Shikoku-island surrounded by the Seto-inland sea and mountains. Most residents are engaged in farming and do'nt go another province for work. The Japanese old customs are still lingering on this district. It is a custom of this area from early times that the eldest son succeed to his father's farming and the other go to city for work. The social and hygienic conditions are moderately good compared to the ones of the average Japanese countryside. One thousand donors, about $2 \%$ of the population were tested for HBAg and $\mathrm{HBAb}$. In all instances serum was taken from persons having no signs or symptom of liver disease. The samples were collected at the central laboratory in glass tubes and they were frozen until ready for testing.

Assays for $\mathrm{HBAg}$ and $\mathrm{HBAb}$ were done by Ausria II-125 and Ausab as indicated by the manufacturer. All specimens were also tested for glutamic-oxalacetic transaminase activity, glutamic-pyruvic transaminase activity, bilirubin, and alkaline phosphatase activity.

Jap J Med Vol 16, No 3 (July 1977)

\section{RESULTS}

Table 1. Prevalence rate according to age and sex of hepatitis $B$ antigen among blood donors.

\begin{tabular}{|c|c|c|c|c|c|c|c|c|c|}
\hline \multirow[b]{2}{*}{$\begin{array}{l}\text { Age } \\
\text { group }\end{array}$} & \multicolumn{3}{|c|}{ Males } & \multicolumn{3}{|c|}{ Females } & \multicolumn{3}{|c|}{ Both } \\
\hline & $\begin{array}{l}\text { Total } \\
\text { No. }\end{array}$ & $\begin{array}{l}\text { No. } \\
\text { with } \\
\text { HBAg }\end{array}$ & $\begin{array}{l}\text { Rate } \\
\text { per } \\
100\end{array}$ & $\begin{array}{l}\text { Total } \\
\text { No. }\end{array}$ & $\begin{array}{l}\text { No. } \\
\text { with } \\
\text { HBAg }\end{array}$ & $\begin{array}{l}\text { Rate } \\
\text { per } \\
100\end{array}$ & $\begin{array}{l}\text { Total } \\
\text { No. }\end{array}$ & $\begin{array}{l}\text { No. } \\
\text { with } \\
\text { HBAg }\end{array}$ & $\begin{array}{l}\text { Rate } \\
\text { per } \\
100\end{array}$ \\
\hline$<20$ & 32 & 1 & 3.13 & 19 & 0 & 0 & 51 & 1 & 1.96 \\
\hline $20-29$ & 306 & 15 & 4.90 & 89 & 1 & 1.12 & 395 & 16 & 4.05 \\
\hline $30-39$ & 231 & 1 & 0.43 & 52 & 0 & 0 & 283 & 1 & 0.35 \\
\hline $40-49$ & 150 & 0 & 0 & 53 & 0 & 0 & 203 & 0 & 0 \\
\hline 50 & 60 & 3 & 5.0 & 8 & 0 & 0 & 68 & 3 & 4.41 \\
\hline Total & 779 & 20 & 2.57 & 221 & 1 & 0.45 & 1,000 & 21 & 2.10 \\
\hline
\end{tabular}

Table 2. Prevalence rate according to age and sex of hepatitis B antibody among blood donors.

\begin{tabular}{|c|c|c|c|c|c|c|c|c|c|}
\hline \multirow[b]{2}{*}{$\begin{array}{l}\text { Age } \\
\text { group }\end{array}$} & \multicolumn{3}{|c|}{ Males } & \multicolumn{3}{|c|}{ Females } & \multicolumn{3}{|c|}{ Both } \\
\hline & $\begin{array}{l}\text { Total } \\
\text { No. }\end{array}$ & $\begin{array}{l}\text { No. } \\
\text { with } \\
\text { HBAb }\end{array}$ & $\begin{array}{l}\text { Rate } \\
\text { per } \\
100\end{array}$ & $\begin{array}{l}\text { Total } \\
\text { No. }\end{array}$ & $\begin{array}{l}\text { No. } \\
\text { with } \\
\text { HBAb }\end{array}$ & $\begin{array}{l}\text { Rate } \\
\text { per } \\
100\end{array}$ & $\begin{array}{l}\text { Total } \\
\text { No. }\end{array}$ & $\begin{array}{l}\text { No. } \\
\text { with } \\
\text { HBAb }\end{array}$ & $\begin{array}{l}\text { Rate } \\
\text { per } \\
100\end{array}$ \\
\hline$<20$ & 32 & 6 & 18.8 & 19 & 3 & 15.8 & 51 & 9 & 17.6 \\
\hline $20-29$ & 306 & 45 & 14.7 & 89 & 10 & 11.2 & 395 & 55 & 13.9 \\
\hline $30-39$ & 231 & 48 & 20.8 & 52 & 9 & 17.3 & 283 & 56 & 19.8 \\
\hline $40-49$ & 150. & 43 & 28.7 & 53 & 9 & 17.0 & 203 & 52 & 25.6 \\
\hline 50 & 60 & 14 & 23.3 & 8 & 4 & 50.0 & 68 & 18 & 26.5 \\
\hline Total & 779 & 156 & 20.0 & 221 & 35 & 15.8 & 1,000 & 190 & 19.0 \\
\hline
\end{tabular}

Table 3. Relationship of HBAg, HBAb and S-GOT.

\begin{tabular}{|c|c|c|c|c|c|c|c|c|c|}
\hline \multirow[b]{2}{*}{$\begin{array}{l}\text { HBAg } \\
\text { and } \\
\text { HBAB }\end{array}$} & \multicolumn{3}{|c|}{ Males } & \multicolumn{3}{|c|}{ Females } & \multicolumn{3}{|c|}{ Both } \\
\hline & $\begin{array}{l}\text { Total } \\
\text { No. }\end{array}$ & $\begin{array}{l}\text { No. with } \\
\text { normal } \\
\text { GOT }\end{array}$ & $\begin{array}{l}\text { No.with } \\
\text { elevated } \\
\text { G0T }\end{array}$ & $\begin{array}{l}\text { Total } \\
\text { No. }\end{array}$ & $\begin{array}{l}\text { No.with } \\
\text { normal } \\
\text { G0T }\end{array}$ & $\begin{array}{l}\text { No.with } \\
\text { elevated } \\
\text { GOT }\end{array}$ & $\begin{array}{l}\text { Total } \\
\text { No. }\end{array}$ & $\begin{array}{l}\text { No.with } \\
\text { normal } \\
\text { GOT }\end{array}$ & $\begin{array}{l}\text { No.with } \\
\text { eievated } \\
\text { GOT }\end{array}$ \\
\hline HBAgS & 2 & 10 & 50 & 1 & \%) & 010 & 21 & $.2 \%)$ & 6) $1 / 4$ \\
\hline$A B(+)$ & 156 & $151(96$. & 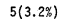 & 35 & $35(100 \%)$ & $0(0$ & 191 & $186(97.4 \%)$ & $5(2.6 \%)$ \\
\hline i & ) 603 & & & 185 & & & 788 & & \\
\hline Total & 779 & $770(98.8 \%)$ & $9(1.2 \%)$ & 221 & $221(100 \%)$ & $0(0 \%)$ & 1,000 & $997(99.1 \%)$ & ) $9(0.9 \%)$ \\
\hline
\end{tabular}

The frequency of HBAg, detectable by the RIA, in sera from normal blood donors is summarized in Table 1. HBAg was detected in sera of 21 of the 1,000 donors. The antigen was found more frequently in male donors than female donors. The overall prevalence rate was $2.57 \%$ male donors and $0.45 \%$ female donors. In both sexes, the highest prevalence was observed in the group 20-29 year of age.

Table 2 shows the incidence of $\mathrm{HBAb}$ in the donors. 190 individual sera from 1,000 healthy donors were found to be $\mathrm{HBAb}$ positive. The prevalence of the antibody was slightly higher among male than female. HBAb was detected in $20.0 \%$ 
of male in comparison to $15.8 \%$ of female. The frequency of the antibody increased with advancing age.

Elevated glutamic oxalacetic transaminase levels were observed in 9 males (Table 3). Of these donors, HBAb were detectable in one donor and 5 donors, respectively. In all sera from female donors, serum transaminase activities were within the normal range. None of specimen from the donors showed an elevation of alkaline phosphatase or bilirubin level.

\section{DISCUSSIONS}

The geographic distribution and sex-and age-specific prevalence of $\mathrm{HBAg}$ in normal population were decribed in several reports $(1,20)$. The antigen was quite rare in normal Americans and was not uncommon in several tropical populations. It also occured in Japanese and Mediterranean population in lower frequency (about 1\%). West African population contained the antigen in high frequency $(1,20)$. The frequency was invariably higher in the younger than in the older age groups, and in males than in females in nearly all the population $(1,20)$.

The incidence of HBAg in blood donors by $\mathrm{MO}$ technique was reported from Paris (6.2\%) (21), Minnesota (0.06-1.47\%) (22), Copenhagen (0.18\%) (23), Tokyo (1.0\%) (4) and from Taiwan (3.1\%) (24), and by IEOP technique was reported from Glasgow $(0,08$ $\%$ ) (25), New York (0.15\%) (26), New Orleans (0.7\%) (27), Mainz (0.12\%) (28) and from American Red Cross donor population $(0.10 \%)(29)$. Following the original study in Tokyo by using MO technique, IAHA method was developed and resulted in a 2fold higher incidence of $\mathrm{HBAg}$ (5) than by MO technique (4).

More recently RIA techniques were described that increased the sensitivity of detection of HBAg (10-19) by at least 3 to 8 times as many positive sera as the CF, MO or IEOP technique. The Ausria II-125 methodology which was used in our study had demonstrated a very high degree spe- cificity when compared with the earlier RIA technique (19).

As shown in Table 1, a slightly higher incidence $(2.1 \%)$ was found in Mitoyo than in Tokyo (2.0\%). The actual prevalence rates in these areas will be in the same oder since IAHA technique is quite sensitive (5). The incidence of HBAg in the other parts of Jayan was reported to be $3.5 \%$ in Akita (6) (by IAHA), 2.1\% in OkuHida (7) (by IAHA), 2.1\% in Gifu (8) (by RPHA), and $2.3 \%$ in Aki (9) (by IAHA). An excess prevalence of HBAg among male donors and young adults was observed as reported by the other authors $(1,5-8,20,23$, 26).

$\mathrm{HBAb}$ carriers will increase as exposure to HBAg increases (30-33). It was stated that HBAg exposure became apparent when pre-existing $\mathrm{HBAb}$ increased in its titer or when seroconversion from $\mathrm{HBAb}$ negative to positive is noted (32). Therefore the prevalence rate of $\mathrm{HBAb}$ would suggest the extent of exposure to $\mathrm{HBAg}$ $(24,34)$. We obtained a lower incidence of $\mathrm{HBAb}$ in Mitoyo by the most sensitive method (Table 2) than in Akita $(24.8 \%$ by PHA) (6), in Oku-Hida (25.8\% by $\mathrm{PHA}$ ) (7) and in Aki (22.2\% by IEOP) (9). The result suggests a lower extent of past exposure to $\mathrm{HBAg}$ in Mitoyo than the other parts. An association of $\mathrm{HBAg}$ with age (age group:20-29) was observed in Mitoyo as described in the other parts of this contry $(6,7,9,23)$.

The incidence of donors with elevated serum transaminase activity was only $0.9 \%$. Strikingly, all sera from 221 female donors were found to have normal serum transaminase levels. A more higher prevalence rate of elevated serum transaminase activity was observed in Oku-Hida (3.7\%) (7) and Aki (19.0\%) (9). The elevated serum transaminase activity was determined in $4.8 \%$ of donors with HBAg. A lower incidence was detected in Oku-Hida (0.4) (7) and higher incidences were determined in $\mathrm{Aki}$ (38.5\%) (9) and in New York (23\%) (26). A significantly lower incidence of $\mathrm{HBAb}$ carrier with elevated serum transaminase acti- 
vity was determined in Mitoyo (2.6\%) than Oku-Hida (8.5\%) (7) and Aki (18.4\%) (9).

Since a recent report (35) suggested that normal serum transaminase activity in $\mathrm{HBAg}$ or HBAb carrier does not exclude significant chronic damage which may be detected histologically, we are planing a follow-up study including liver biopsy of these carriers.

ACKNOWLEDGEMENTS: We wish to express our appreciation to Prof. H. Nagashima for his guidance, and to Mr. Y. Ishii and Mr. S. Yokoyama for their excellent technical assistances.

\section{REFERENCES}

1) Blumberg BS, Sutnick AI, London WT: Hepatitis and leukemia: Their relation to Australia antigen. Bull NY Acid Med 44 : 1566-1586, 1968.

2) Prince AM, Hargrove RL, Jeffries GH: The role of serum hepatitis virus in chronic liver disease. Clin Res 17: 461, 1969.

3) Blumberg BS, Sutnick AI, London WT: Australia antigen as a hepatitis virus: Variation in host responce. Am J Med 48: 18, 1970.

4) Okouchi K, Murakami S: Observation on Australia antigen in Japanese. Vox sang 15 : 374-385, 1968.

5) Okouchi K, Murakami M, Haguino $Y$, Saito N: Evaluation of fraquency of Australia antigen in blood donors of Tokyo by means of immune adherence hemagglutination technique. Vox Sang 19: 332-337, 1970.

6) Takemoto $Y$, Kumagaya $M$, Sasaki $M$, Tsuda F, Yamashita Y, Takimoto G, Konishi T: Sex-and age-specific distribution of anti-Au antibody in donors of Akita prefecture. Igakunoayumi (Tokyo) $82: 206-207$, 1972.

7) Udo K, Kojima M, Miyagawa T, Kametani M, Fukuta N, Takahashi Y, Takakuwa K, Okuda T, Otaka M, Tsuji T, Kumagawa K, Sugiyama $M$, Iriyama $H$, Tokimitsu $N$, Mayumi $\mathbf{M}$ : Distribution of HB-antigen, $\mathrm{HB}$-antibody and subtype of $\mathrm{HB}$-antigen in Shokawa village (Hida region) which is relatively closed. Acta Hepatol Jap 15: 505509, 1974.

8) Shimizu M, Takahashi H, Egawa M, Ozawa
N, Sakamoto Y, Mayumi M: The prevalence of HBs-Ag and anti-HBs in young people in Gujo-gun, Gifu. Acta Hepatol Jap 16 : 872-883, 1975.

9) Naito K: Epidemiological and clinical studies of hepatitis $\mathrm{B}$ surface antigen positive persons in the epidemic areas of viral hepatitis: Part I: Epidemiological studies. Acta Hepatol Jap 17: 272-287, 1976.

10) Walsh JH, Ylow R, Berson SA: Detection of Australia antigen and antibody by means of radioimmunoassay techniques. J Infect Dis 121: 550-554, 1970.

11) Lander JJ, Alter HJ, Purcell RH: Frequency of antibody to hepatitis-associated antigen as measured by a new radioimmunoassay technique. J Immunology 106 : 1166$1171,1971$.

12) Hollinger FB, Vorndam V, Dressman GR : Assay of Australia antigen and antibody and solid-phase radiommunoassay techniques and comparison with the passive hemagglutination methods. J Immunology 107 : 1099-1111, 1971.

13) Ling CM, Overby LR: Prevalence of hepatitis $B$ virus antigen as revealed by direct radioimmunoassay with ${ }^{125} \mathrm{I}$-antibody. J Immunology 109 : 834-841, 1972.

14) Alter HJ, Holland PV, Purcell RH, Gerin JL: The Ausria test: Critical evaluation of sensitivity and specificity. Blood 42 : 947-957, 1973.

15) Prince AM, Brotman B, Jass D, Ikram H: Specificity of the direct solid-phase radioimmunoassay for detection of hepatitis-B antigen. Lancet 1: 1346-1350, 1973.

16) Hollinger FB, Aach RD, Gitnick GL, Roche JK, Melnick JL: Limitations of solid-phase radioimmunoassay for $\mathrm{HB} \mathrm{Ag}$ in reducing frequency of post-transfusion hepatitis. N Engl J Med 289 : 385-391, 1973.

17) Overy LD, Decker RH, Ling CM: Nonspecificity of hepatitis B antigen detected with iodine-125-labeled antibody. Science 182: 1368-1371, 1973.

18) Dodd RY, Ni LY, Mallin WS, Greenwalt TJ : Hepatitis B (surface) antigen testing by radioimmunoassay: Experience in a very large volunteer donor population. Am J Clin Pathol 63 : 847-853, 1975.

19) Ni LY, Dodd RY, Salmon BR, Greenwalt TJ: The solid phase radioimmunoassay technique for hepatitis B (surface) antigen: Effects of progressive modification. Trans- 
fusion 15:608-611, 1975.

20) Prince AM: Prevalence of serum-hepatitis related antigen $(\mathrm{SH})$ in different geographic regions. Am J Trop Med and Hyg 19: 872-879, 1970.

21) Soulier JP, Courouce-Pauty AM, BenamonDjiane D: Study of the Australia antigen and of the corresponding antibody in blood donors in Paris. Vox Sang 19: 345-351, 1970.

22) Taswell HF, Shoter R, Poncelet TK, Maxwell NG: Hepatitis-associated antigen in blood donor populations: Relationship to posttransfusion hepatitis. JAMA 214: 142144, 1970.

23) Banke O, Dybkjaer E, Nordenfelt E, Reinicke $\mathrm{V}$ : Australia antigen and antibody in 10,000 danish blood-donors. Lancet 1:860861, 1971.

24) Hsia S, Chen SG, Shen FG, Shin BY: Australia antigen and antibody in blood donors and patients with blood disorders. Transfusion $13: 89-93,1973$.

25) Wallace J, Milne GR, Barr A: Total screening of blood donations for Australia (hepatitis associated) antigen and its antibody. Brit Med J 1 : 663-664, 1972.

26) Szmuness W, Prince AM, Brotman B, Hirsch RL : Hepatitis $B$ antigen and antibody in blood donors: An epidemiologic study. J Infect Dis 127 : 17-25, 1973.

27) Carrera AN, Bryant LR, Leonard GL : Screening of blood donors for hepatitis-associated antigen and antibody. Am J Clin Pathol 60 : 445-449, 1973.
28) Arndt-Hanser A, Pyka R: Blood bank service screening of Australia antigen and antibodies at Mainz, Germany. Vox Sang Suppl 24 : 72-75, 1973.

29) Dodd RY, Holland PV, Ni LY, Smith HM Greenwalt TJ : Hepatitis $B$ antigen : Regional variation in incidence and subtype ratio in the American Red Cross donor population. Am J Epidemiol 97: 111-115, 1973.

30) Lewis TL, Alter HJ, Chalmers TC, Holland PV, Purcell RH, Alling DW, Young D, Frenkel LD, Lee SL, Lamson ME: A comparison of the frequency of hepatitis B antigen and antibody in hospital and nonhospital personnel. N Eng J Med 289: 647-651, 1973.

31) Kunst VAJM Bloo JH: Australia antigen and antibody in laboratory and other hospital personnel. Vox Sang 24 : 61-64, 1973.

32) Swartzberg J, Kern F, Hepatitis B antibody. JAMA 224 : 527, 1973.

33) Wands JR, Walker JA, Davis TT, Waterbury LA, Owens AH, Carpenter CGJ: Hepatitis $B$ in an oncology unit. N Engl J Med 291; 1371-1378, 1974.

34) Delman M, Nadler J, Fumia F, Szmuness W, Cherubin C: Anti-hepatitis Bs antigen in Medical Personnel. Arch Intern Med 135: 1624, 1975.

35) Russel RI, Goldberg DM, Allan JG, Mecsween RNM, Wallace J: A study of hepatic disease in Australia antigen and antibody-positive blood donors. Digest Dis 19 : 113-121, 1974。 